Int. J. Morphol.,

34(2):503-509, 2016.

\title{
Morphological Study of the Iris Musculature in Diurnal and Nocturnal Raptors
}

\author{
Estudio Morfológico de la Musculatura del Diafragma en Aves Rapaces Diurnas y Nocturnas
}

\author{
Alessandra Coli*; Maria Rita Stornelli*; Giovanni Barsotti*; Renato Ceccherelli**; \\ Eleonora Giani***; Carla Lenzi* \& Elisabetta Giannessi* $^{*}$
}

COLI, A.; STORNELLI, M. R.; BARSOTTI, G.; CECCHERELLI, R.; GIANI, E.; LENZI, C. \& GIANNESSI, E. Morphological study of the iris musculature in diurnal and nocturnal raptors. Int. J. Morphol., 34(2):503-509, 2016.

SUMMARY: In literature it is established that the iris musculature consists of striate muscle fibers in birds while in mammals it consists of smooth muscles. Some authors report the presence of smooth muscle tissue also in the iris of some species of birds. In the present study we report on the iris muscle tissues (type of tissue, direction and mean diameter of muscle fibers or cells) in five species of Accipitriformes (diurnal raptors) and four species of Strigiformes (nocturnal raptors) because they show different way of life depending of their predatory behavior. This morphological study was carried out from raptors died or euthanized at the Wild Life Rescue Centre of Sea and Water birds in Livorno (Italy). From histological examination of iris serial radial sections we find both striated and smooth musculature even if with marked differences among analyzed species, not directly correlated with diurnal or nocturnal lifestyle. Striated fibers are always present, mainly with cross direction, throughout the iris stroma, while the histological differences concern the smooth cells. Indeed, harrier and sparrow hawk (Accipitriformes) and great horned owl and little owl (Strigiformes) show a compact layer of cross smooth muscle cells throughout the iris stroma. In the other species analyzed smooth muscle cells are slightly detectable as scattered or not detectable. Since the cross smooth muscle tissue allows to maintain a myotic state for extended periods of time, our results might be correlated more to the predatory behavior than the taxonomic order.

KEY WORDS: Iris; Striated musculature; Smooth musculature; Morphology; Raptors.

\section{INTRODUCTION}

For a long time in the avian iris a striated musculature has been described (Lewis, 1903; Hodges, 1974; Sisson et al., 1975; King \& McLelland, 1975). The presence of structural features typical of striated muscles, such as richness in mitochondria and large amounts of sarcoplasmic reticulum in the iris of the birds (Hess, 1966; Zenker \& Krammer, 1967; Pilar \& Vaughan, 1971), confirmed this particular musculature.

The presence of striated muscle fibers is clearly manifest also in clinical field. Indeed, mydriasis during an ophthalmologic examination has been obtained by local use of Neuro Muscular Blocking Agents (NMBAs) in some species of conscious raptors (Barsotti et al., 2010a, 2010b, 2012). In contrast, parasympatholytic drugs used to dilate pupils in mammals (Richardson, 1964) are ineffective in birds.
As in mammals, the avian iris musculature is organized into sphincter and dilator muscles whose fibers are respectively arranged into cross and radial bundles. The origin of such fibers is actually subject to various assumptions. One hypothesis expected that muscle fibers could derive from multipotent stem cells of the optic cup neuroepithelium: indeed, in chicken, dilator muscle arises from the surface of anterior epithelium while the sphincter one has epithelial buds as precursor in the pupillary region. Confirming the striated appearance, the irideal muscles show positivity against chicken skeletal muscle myosin (Ferrari $\&$ Koch, 1984). On the contrary, various hypotheses agree on a smooth to striate muscle transition of iris musculature: during ontogenesis of chicken iris, the smooth muscle represents an intermediate stage of differentiation toward striated muscle. Using specific monoclonal antibodies Volpe et al. (1993) observing an appearance of cells with

\footnotetext{
* Department of Veterinary Sciences, University of Pisa, Pisa, Italy.

** C.R.U.M.A. L.I.P.U. Wild Life Rescue Centre of Sea and Water Birds, Livorno, Italy.

**** Private practitioner, Firenze, Italy.
} 
myoepithelial features at pupillary margin, suggest a possibility that these cells represent a future precursor of smooth muscle cells. However, the final differentiation stage is toward striate muscles, well visible in the middle third of iris.

However, some authors recognize smooth muscle cells in the structure of the adult avian iris. Indeed, Gabella \& Clarke (1983) and Scapolo et al. (1988) highlight that, in chicken iris, besides striated fibers, smooth muscle cells are recognizable originating from separated lineages: the smooth muscle cells originate from irideal posterior epithelium and remain at the pupillary edge; the striated muscle fibers differentiate from mesenchymal cells of iris stroma. Yamashita \& Sohal (1986) confirm this organization for iris of domestic duck and quail: during development, mesenchymal cells progressively migrate between bundles of smooth cells and here they become striated muscle fibers.

Among birds some specific modifications of eye anatomy are linked to the particular way of life. An example is represented by raptors that have various adaptations in maximizing their visual acuity such as a variable high density of receptors and a monocular or binocular vision for an accurate judgement of distances. These morpho-functional features are particularly detectable between diurnal and nocturnal raptors. Diurnal raptors are characterized by visual acuity: indeed they have larger (for maximum spatial resolution), and longer (relative to the corneal diameter) eyes to ensure greater visual acuity, together with a greater number of retinal cones, than nocturnal raptors. However, their vision is poor in low light level (Martin, 1993) so they remain in the nest during the evening and night (Whittow \& Sturkie, 1998). On the contrary nocturnal raptors show eyes optimized for visual sensitivity, with large cornea in relation to length of the eye, absence of retinal cones and large numbers of closely packed retinal rods allowing the bird to see better in low light conditions (Sinclair, 1985).

The iris musculature of the raptors is not currently investigated. Oehme (1969) pointed out the organization of iris musculature of various orders of birds including Falconiformes as diurnal raptors and Strigiformes as nocturnal raptors. Oliphant et al. (1983) combined the study of the iris anatomy with the examination of pupillary reflex in great horned owl. In both studies striated muscle fibers and smooth muscle cells have been recognized in the iris musculature. It is supposed that the striated fibers allow for a rapid pupillary response while of smooth cells allow for maintaining the myotic state for a long period of time.

The aim of the present study was to describe the iris musculature of various species of diurnal and nocturnal raptors in order to correlate the type and direction of muscle tissue with different lifestyles of raptors analyzed.

\section{MATERIAL AND METHOD}

Eighteen eyes from five Accipitriformes: harrier (Circaetus gallicus), hawk (Falco peregrinus), kestrel (Falco tinniculus), buzzard (Buteo buteo) and sparrow hawk (Accipiter nisus) and from four Strigiformes: tawny owl (Strix aluco), barn owl (Tyto alba), little owl (Athene noctua) and great horned owl (Bubo bubo) were used in this study. The eyes, collected from raptors died or euthanized at the Wild Life Rescue Centre of Sea and Water birds in Livorno (Italy), were free from ocular diseases as observed through a complete ocular examination performed at the time of admission to the Centre. All the experimental procedures were conducted following the current guidelines of protection of animals used for scientific purposes. The eyes were enucleated after death or euthanasia and were fixed in $4 \%$ buffered formalin solution. Each eyeball was cleaned of all fascia and extraocular musculature and hemisected longitudinally into temporal and nasal halves. One half of the eyeball was processed and embedded in JB-4 plastic resin. From the other half, the iris was isolated and embedded in JB-4 plastic resin. From both hemisected eyeball and isolated iris, serial sections $5 \mu \mathrm{m}$ thick were cut radially by a Reichert-Jung microtome and stained with Toluidine blue and Mallory trichrome for microscopic examination. The specimens were assessed under Leitz Diaplan microscope.

\section{RESULTS}

\section{Diurnal raptors}

Cross striated musculature. These are fibers of small diameter (Table I) and are the most represented, with the exception of the sparrow hawk in which the cross smooth musculature is prevalent. In all the diurnal raptors, at the level of peripheral third of the iris (near the ciliary body) these fibers are separated by abundant loose connective tissue (Fig. 1a). Their diameter is larger than that of other portions of the iris (Table I). In the central third of the iris the fiber bundles are nearing and compacting, localized mainly near the corneal endothelium (Fig. 1b). At the level of the pupillary edge the fiber bundles show a reduction in diameter (Table I) and lie progressively in the whole thickness of the stroma. At this level, in allspecies of diurnal raptors only crossstriated musculature is present (Fig.1c). 
Table I. Morphometric data $(\mu \mathrm{m} \pm \mathrm{SD})$ of striated and smooth musculature of diurnal raptors iris.

\begin{tabular}{llllll}
\hline & Buzzard & Harrier & Hawk & Kestrel & Sparrow hawk \\
\hline Cross striated fibers diameter & & & & & \\
$\quad$ Peripheral third & $8.85( \pm 1.19)$ & $12.62( \pm 3.23)$ & $9.7( \pm 1.95)$ & $4.87( \pm 1.52)$ & $7.51( \pm 2.09)$ \\
$\quad$ Central third & $7.18( \pm 1.5)$ & $8.59( \pm 1.78)$ & $10.2( \pm 2.52)$ & $4.66( \pm 0.9)$ & $6.13( \pm 1,14)$ \\
$\quad$ Pupillary third & $4.74( \pm 0.68)$ & $6.13( \pm 1.08)$ & $10( \pm 2.17)$ & $2.94( \pm 0.37)$ & $4.15( \pm 0.98)$ \\
Longitudinal striated fibers diameter & $3.91( \pm 0.31)$ & $4.65( \pm 0.7)$ & $6.37( \pm 0.61)$ & $4.06( \pm 0.45)$ & $6.19( \pm 1.89)$ \\
Smooth cells diameter & - & $9.5( \pm 1.05)$ & - & - & $10( \pm 1.85)$ \\
\hline
\end{tabular}

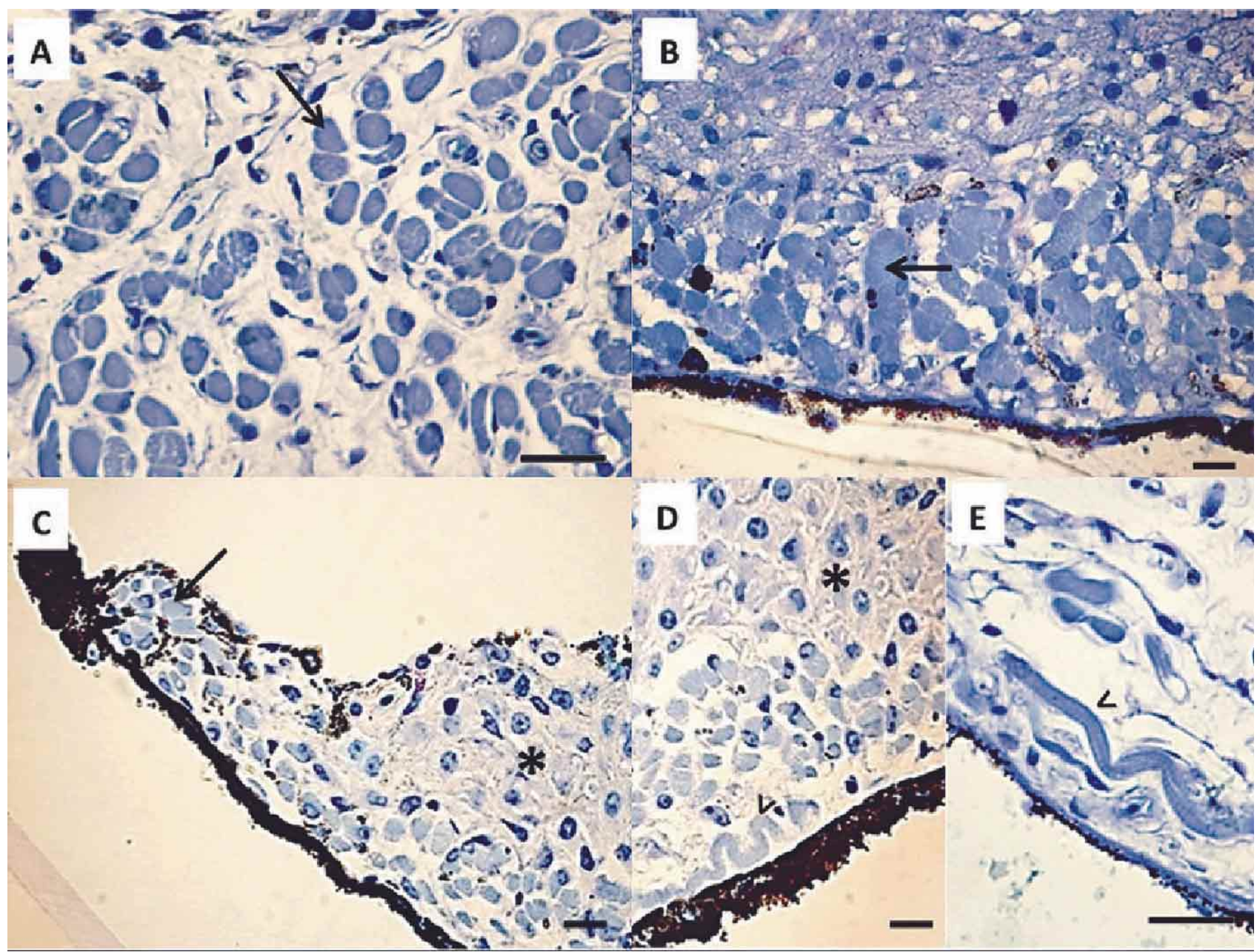

Fig. 1. Radial histological sections of diurnal raptors iris. A) Harrier, peripheral third of iris: cross-striated fibers (arrow). B) Harrier, central third of iris: cross-striated fibers (arrow) (Toluidine blue). C) Sparrow hawk, pupillary edge: cross-striated fibers (arrow); cross smooth cells (asterisk) (Toluidine blue). D) Sparrow hawk, central third of iris: longitudinal striated fibers (empty arrowhead); cross smooth cells (asterisk) (Toluidine blue). E) Harrier, peripheral third of iris: longitudinal striated fibers (empty arrowhead) (Toluidine blue). Scale bar: $\mathrm{A}$ and $\mathrm{E}=20 \mu \mathrm{m} ; \mathrm{B}, \mathrm{C}$ and $\mathrm{D}=10 \mu \mathrm{m}$.

Longitudinal striated musculature. These fibers are much less represented compared to the cross ones and, when present, they mainly lie in contact with pigmented epithelium. The bundles are visible as isolated and wavy fibers (Fig. 1d and 1e), which tend to reduce gradually from the peripheral third of the iris until the pupillary edge, where they disappear. As reported in Table I, their diameter is like the cross fibers of the ciliary third of the iris. In buzzard few fibers are detectable among cross striated and smooth musculature.

Cross smooth musculature. This musculature shows different features in the analyzed species. Indeed, in harrier (Fig. 1b, 1c and 1d) and sparrow hawk it is organized in a layer of uniform thickness throughout the iris stroma characterized by six to eight rows of cells, below the corneal 
endothelium. In buzzard these smooth cells are organized in fewer cell rows (from two to three). In hawk and kestrel they are slightly detectable, mixed among the striated fibers, always near the corneal endothelium. In all diurnal raptors these smooth cells are not visible at the level of the pupillary edge for the only presence of cross striated musculature (Fig. 1c).

Longitudinal smooth musculature. A clear longitudinal smooth musculature in whole iris stroma is not detectable.

\section{Nocturnal raptors}

Cross-striated musculature. It is organized in few bundles of fibers, separated by abundant loose connective tissue. Sometimes some isolated fibers immersed in the stroma are observed. Cross-striated musculature presents different features depending of raptor species analyzed.
In great horned owl and little owl this musculature is a few represented: absent in the peripheral third of iris (near the ciliary body), it is detectable as slender bundles between the layer of cross smooth muscle cells and the corneal endothelium (Fig. 2a and 2b). The fiber diameter decreases toward the papillary edge in great horned owl and less in little owl (Table II). At this level the crossstriated fibers lie with smooth cells.

In the tawny owl (Fig. 2c) and barn owl (Fig. 2d) the cross-striated fibers are detectable throughout the stroma of the iris. Their diameter slightly decreases from the peripheral third toward the pupillary edge (Table II) where they are the only muscle fibers found in barn owl. On the contrary, they are not detectable at this level in tawny owl (Fig. 2c).

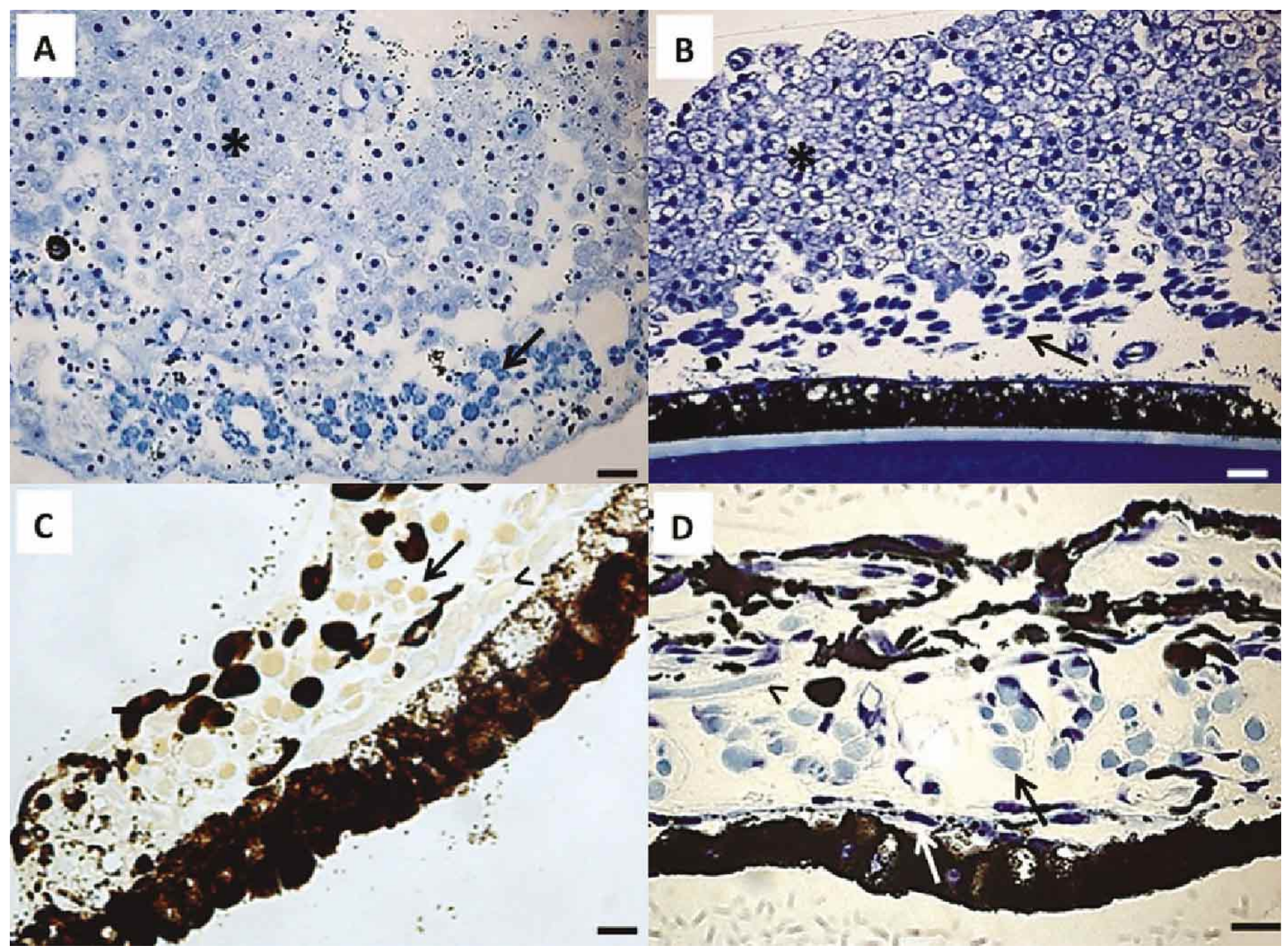

Fig. 2. Radial histological sections of nocturnal raptors iris. A) Great horned owl, central third of the iris: cross-striated fibers (arrow), cross smooth cells (asterisk) (Toluidine blue). B) Little owl, central third of the iris: cross-striated fibers (arrow), cross smooth cells (asterisk) (Toluidine blue). C) Tawny owl, pupillary edge: cross-striated fibers (black arrow), longitudinal striated fibers (empty arrow) (Mallory). D) Barn Owl, central third of the iris: cross-striated fibers (black arrow), longitudinal striated fibers (empty arrow) myoephitelium (white arrow) (Toluidine blue). Scale bar: A, B and C=20 $\mu \mathrm{m} ; \mathrm{D}=10 \mu \mathrm{m}$. 
Table II. Morphometric data $(\mu \mathrm{m} \pm \mathrm{SD})$ of striated and smooth musculature of nocturnal raptors iris.

\begin{tabular}{|c|c|c|c|c|c|}
\hline \multirow{3}{*}{$\begin{array}{l}\text { Zross striated fibers } \\
\text { liameter }\end{array}$} & \multirow[b]{2}{*}{ Peripheral third } & \multirow{2}{*}{$\begin{array}{c}\text { Barn owl } \\
4.3( \pm 0.91)\end{array}$} & \multirow{2}{*}{$\begin{array}{c}\text { Great horned owl } \\
---\end{array}$} & \multirow{2}{*}{$\begin{array}{c}\text { Little owl } \\
---\end{array}$} & \multirow{2}{*}{$\frac{\text { Tawny owl }}{5.65( \pm 0.77)}$} \\
\hline & & & & & \\
\hline & Central third & $3.52( \pm 0.47)$ & $6.46( \pm 1.22)$ & $4.88( \pm 0.97)$ & $5.81( \pm 0.87)$ \\
\hline & Pupillary third & $3.05( \pm 0.81)$ & $4.79( \pm 1.05)$ & $4.58( \pm 0.91)$ & $4.7( \pm 1.35)$ \\
\hline \multicolumn{2}{|c|}{-ongitudinal striated fibers diameter } & $3.53( \pm 0.41)$ & $6.62( \pm 0.47)$ & $3.65( \pm 0.77)$ & $4.75( \pm 0.59)$ \\
\hline \multicolumn{2}{|c|}{ I mooth cells diameter } & --- & $10.86( \pm 1.2)$ & $11.33( \pm 1.6)$ & --- \\
\hline
\end{tabular}

Longitudinal striated musculature. The longitudinal striated fibers are much less represented than cross ones. In great horned owl and in little owl there are no detectable true longitudinal fibers.

In tawny owl and barn owl (Fig. 2c and 2d) these fibers are isolated and mixed with cross-striated fibers. They are small in diameter and, as in diurnal raptors, they resemble the cross one. In great horned owl they show the largest diameter (Table II).

Cross smooth musculature. It shows different features among species analyzed. In great horned owl and in little owl this musculature is the most detectable in the whole iris and lie near the corneal endothelium such as dense layer until the pupillary edge (Fig. 2a and 2b). In the cell cytoplasm the presence of numerous vacuoles can be better evidenced in little owl (Fig. 2b). Smooth cells diameter is alike in the whole iris (Table II). In tawny owl and barn owl smooth cells are not detectable in the iris stroma, from peripheral third to the central third of the iris. At the pupillary edge in barn owl they are not detectable, while in tawny owl these cells can join or replace the cross striated fibers (Fig. 2c).

Longitudinal smooth musculature. Also in the iris stroma of nocturnal raptors it is not visible a longitudinal smooth musculature. Near the pigmented epithelium the presence of a myoepithelium, with basal processes radially arranged including melanin granules, more apparent in tawny owl and in barn owl (Fig. 2d) is detectable.

\section{DISCUSSION}

The most of the current literature and texts (Hodges, 1974; Sisson et al.; King \& McLelland) describe only striated musculature in the iris of birds, even if some authors observed smooth musculature in the development of the iris only. Instead, we point out both striated and smooth musculatures in the iris of diurnal and nocturnal raptors examined with remarkable differences among analyzed species. These results agree with the observations of Oehme in many species of birds including some raptors, and with results of Oliphant et al., in the great horned owl regarding on the differences in the composition of iris musculature correlated to the variable degree of contraction between striated and smooth components.

Regarding the organization of the striated musculature, in all diurnal raptors the cross fibers are present throughout the length of the iris, progressively packaged towards the pupillary edge where they are the only muscular component found. Among the nocturnal raptors, the distribution of cross fibers varies according the species: in tawny owl and barn owl it is arranged as described in diurnal ones while in great horned owl and little owl these fibers are missing in the third iris ciliary.

In both diurnal and nocturnal raptors, the longitudinal striated fibers are much less represented compared to the cross ones and, unlike what observed for smooth musculature, their diameter changes in relation to the raptors species and to the localization into the iris stroma. From the morphometrical study is evidenced that their diameter is smaller in nocturnal raptors than in diurnal ones. Moreover we do not point out any fibers with these features in great horned owl and in little owl. The cross smooth musculature fills most of the iris thickness in sparrow hawk and harrier (diurnal raptors) and in great horned owl and little owl (nocturnal raptors). Morphometric analysis shows that smooth cells have similar diameter in all raptors species. On the contrary the longitudinal smooth musculature is poorly represented: in diurnal raptors is hardly detectable while in nocturnal ones is arranged as a myoephitelium, mainly detectable in tawny owl and in barn owl. It lies near the basal layer of the pigmented epithelium of blind retina, as pointed out by Oliphant $e t a l$.

In conclusion, our observations point out that the different distribution of smooth and striated iris musculature among the analyzed raptors species is not directly correlated with diurnal or nocturnal lifestyle, as we would have expected. Indeed, the iris musculature has a similar organization in harrier and sparrow hawk (diurnal raptors) and in great horned owl and little owl (nocturnal raptors). This assertion is mainly due to the presence of a compact layer of smooth muscle cells throughout all the thickness of 
the iris in two species of raptors of different lifestyle, not detectable in the other species. Literature report that the avian iris is not only involved in pupillary reflex (as in mammals) but also in the reflex of lens accommodation, based on contraction of iris musculature which determine changes in curvature of the lens (Ostrin et al., 2011). These reflexes are closely connected to different predatory attitudes. By pupillary and accommodation reflexes the diurnal raptors improve the visual acuity, in condition of high light level, such as some nocturnal raptors, who are suitable to take a daytime life (little owl) or active regardless of day and night (great horned owl). In contrast, the presence of a myoephitelium which allows a contraction state for a long period of time (tawny owl and barn owl) could justify the kind of predatory activity purely nocturnal. Therefore, we think that the results of this study might be justified not only by the different lifestyles (diurnal and nocturnal) but also by the kind of predation of the raptors species.

COLI, A.; STORNELLI, M. R.; BARSOTTI, G.; CECCHERELLI, R.; GIANI, E.; LENZI, C. \& GIANNESSI, E. Estudio morfológico de la musculatura del diafragma en aves rapaces diurnas y nocturnas. Int. J. Morphol., 34(2):503-509, 2016.

RESUMEN: En la literatura, se establece que la musculatura del iris se compone de fibras musculares estriadas en las aves, mientras que en los mamíferos, la forman los músculos lisos. Algunos autores informan también de la presencia de tejido muscular liso en el iris de algunas especies de aves. El presente estudio informa sobre los tejidos musculares del iris (tipo de tejido, la dirección y diámetro de las fibras musculares o células) en cinco especies de Accipitriformes y cuatro especies de Strigiformes que muestran diferentes hábitos en función de su comportamiento depredador. Este estudio morfológico se realizó en aves rapaces que murieron o fueron eutanasiadas en el Centro de Vida Salvaje de Rescate de Aves Marinas y Acuáticas de Livorno (Italia). El examen histológico de secciones seriadas radiales del iris mostró la presencia tanto de musculatura estriada como lisa, aunque con marcadas diferencias entre las especies analizadas, pero sin correlación directa con el estilo de vida diurna o nocturna. Las fibras estriadas estuvieron siempre presentes, principalmente en dirección transversal a lo largo del estroma del iris, mientras que las diferencias histológicas fueron de las células lisas. Tanto el aguilucho y el gavilán (Accipitriformes) como el buho real y el mochuelo (Strigiformes) mostraron una capa compacta de células musculares lisas transversales en todo el estroma del iris. En las otras especies analizadas, las células musculares lisas fueron ligeramente detectables de manera dispersa o no detectables. Dado que el tejido del músculo liso transversal permite mantener un estado miótico durante largos períodos de tiempo, nuestros resultados podrían estar más correlacionados con el comportamiento depredador, y no con el orden taxonómico.

PALABRAS CLAVE: Iris; Musculatura estriada; Musculatura lisa; Morfología; Aves rapaces.

\section{REFERENCES}

Barsotti, G.; Briganti, A.; Spratte, J. R.; Ceccherelli, R. \& Breghi, G. Mydriatic effect of topically applied rocuronium bromide in tawny owls (Strix aluco): comparison between two protocols. Vet. Ophthalmol., 13 Suppl.:9-13, 2010a.

Barsotti, G.; Briganti, A.; Spratte, J. R.; Ceccherelli, R. \& Breghi, G. Bilateral mydriasis in common buzzards (Buteo buteo) and little owls (Athene noctua) induced by concurrent topical administration of rocuronium bromide. Vet. Ophthalmol., 13 Suppl::35-40, 2010b.

Barsotti, G.; Briganti, A.; Spratte, J. R.; Ceccherelli, R. \& Breghi, G. Safety and efficacy of bilateral topical application of rocuronium bromide for mydriasis in European kestrels (Falco tinnunculus). J. Avian Med. Surg., 26(1):1-5, 2012.

Ferrari, P. A. \& Koch, W. E. Development of the iris in the chicken embryo. I. A study of growth and histodifferentiation utilizing immunocytochemistry for muscle differentiation. J. Embryol. Exp. Morphol., 81:153-67, 1984.

Gabella, G. \& Clarke, E. Embryonic development of the smooth and striated musculatures of the chicken iris. Cell Tissue Res., 229(1):37-59, 1983
Hess, A. The fine structure of the striated muscle fibers and their nerve terminals in the avian iris: morphological "twitch-slow" fibres. Anat. Rec., 154:357, 1966.

Hodges, R. D. The Histology of the Fowl. London, Academic Press, 1974.

King, A. S. \& McLelland, J. Outlines of Avian Anatomy. London, Baillière Tindall, 1975.

Lewis, W. H. Wandering pigmented cells arising from the epithelium of the optic cup, with observations on the origin of the M. sphincter pupillae in the chick. Am. J. Anat., 2(3):40516, 1903.

Martin, G. R. Producing the Image. Zeigler, H. P. \& Bischof, H. J. (Eds.). Vision, Brain, and Behavior in Birds. Cambridge (MA), The MIT Press, 1993, pp.5-24.

Oehme, H. Der Bewegungsapparat der Vogeliris. (Eine vergleichende morphologisch-funktionelle Untersuchung). Zool. Jb. Anat., 86:96-128, 1969.

Oliphant, L. W.; Johnson, M. R.; Murphy, C. \& Howland, H. The 
musculature and pupillary response of the great horned owl iris. Exp. Eye Res., 37(6):583-95, 1983.

Ostrin, L. A.; Liu, Y.; Choh, V. \& Wildsoet, C. F. The role of the iris in chick accommodation. Invest. Ophthalmol. Vis. Sci., 52(7):4710-6, 2011

Pilar, G. \& Vaughan, P. C. Ultrastructure and contractures of the pigeon iris striated muscle. J. Physiol., 219(2):253-66, 1971.

Richardson, K. C. The fine structure of the albino rabbit iris with special reference to the identification of adrenergic and cholinergic nerves and nerve endings in its intrinsic muscles. Am. J. Anat., 114:173-205, 1964.

Scapolo, P. A.; Peirone, S. M.; Filogamo, G. \& Veggetti, A. Histochemical, immunohistochemical, and ultrastructural observations on the iris muscles of Gallus gallus. Anat. Rec., 221(3):687-99, 1988.

Sinclair, S. How Animals See: Other Visions of Our World. London, Croom Helm, 1985. pp.88-100.

Sisson, S.; Grossman, J. D. \& Getty R. Sisson and Grossman's The Anatomy of the Domestic Animals. Vol. 2. Philadelphia, W. B. Saunders Co., 1975.

Volpe, P.; Biral, D.; Pizzo, P.; Salviati, G. \& Margreth, A. Ontogenesis of chick iris intrinsic muscles: evidence for a smooth-to-striated muscle transition. Dev. Biol., 159(2):4419, 1993.

Whittow, G. C. \& Sturkie, P. D. Sturkie's Avian Physiology. 5th ed. Londok, Academic Press, 1998. pp.1-18.

Yamashita, T. \& Sohal, G. S. Development of smooth and skeletal muscle cells in the iris of the domestic duck, chick and quail. Cell Tissue Res., 244(1):121-31, 1986.

Zenker, W. \& Krammer, E. Untersuchungen über Feinstruktur und Innervation der inneren Augenmuskulatur des Huhnes. $Z$. Zellforsch. Mikrosk. Anat., 83(2):147-68, 1967.

\author{
Correspondence to: \\ Alessandra Coli \\ Department of Veterinary Sciences \\ University of Pisa \\ Viale delle Piagge, 256122 \\ Pisa \\ ITALY
}

Email: alessandra.coli@unipi.it

Received: 03-02-2016

Accepted: 23-02-2016 